\title{
CHINESE AND JAPANESE PORCELAIN FOR THE DUTCH GOLDEN AGE
}

Trade routes, typology and aesthetic transformation of trade wares are the most intriguing yet difficult aspects in the study of trade ceramics. Big issues as they are, scholars usually focus on either of them. For instance, T. Volker's Porcelain and the Dutch East India Company as Recorded in the Dagh-Registers of Batavia Castle, Those of Hirado and Deshima and Other Contemporary Papers 1602-1682 and The Japanese Porcelain Trade of the Dutch East India Company after 1683 unveil the 17th-century Dutch porcelain trade through studying the documents of the Dutch East Indian Company (Vereenigde Oostindische Compagnie), ${ }^{1}$ Christiaan Jörg's research, such as Fine and Curious: Japanese Export Porcelain in Dutch Collections and Chinese Porcelain in the Rijksmuseum, focuses on the typology of Chinese and Japanese porcelain in the European market from museum and private collections, ${ }^{2}$ while Robert Finlay's The Pilgrim Art: Cultures of Porcelain in World History pictures the circulation of blue-and-white ceramics of the world from the perspective of global history. ${ }^{3}$ Chinese and Japanese Porcelain for the Dutch Golden Age is the latest contribution to the field. This ambitious anthology carries on the query of the aforementioned important issues and pushes forward to conducting dialogue with the latest topics of material culture studies, thereby successfully telling a refreshed story of Chinese export porcelain of the 16th and 17 th centuries.

The editors' effort is evidenced in the structure of the book, which arranges the 13 chapters in a both chronological and thematic order. The story begins with Maarten Prak's 'The Dutch Golden Age: growth, innovation and consumption' that offers the reader the historical background against which the rest of the chapters rest. The second chapter, 'The Iberian royal courts of Lisbon and Madrid, and their role in spreading a taste for Chinese Porcelain in 16th-centry Europe' written by Teresa Canepa, depicts the prehistory of the circulation of Chinese porcelain in Europe before the Dutch intervention. Cynthia Viallé and Sebastiaan Ostkamp contributed the following two chapters, 'Camel cups, parrot cups and Chinese Kraak porcelain items in the Dutch trade records, 1598-1623' and 'The Dutch 17th-century porcelain trade from an archaeological perspective,' respectively, that introduce the VOC's porcelain trade with textual and archaeological material.

Anne Gerritsen's 'Merchants in 17th-century China' brings the narrative to Asia, followed by two chapters on the VOC's activities in the eastern hemisphere. 'The Batavia connection: the Chinese junks and their merchants' by Leonard Blussé and 'The Chinese junks' intermediate trade network in Japanese porcelain for the West' by Miki Sakuraba discuss the Dutch company's East Asian partners and their avid involvement in the shipping of Chinese and Japanese porcelain at the time when China the hegemony in , $_{23}$ 11:21:32pM 


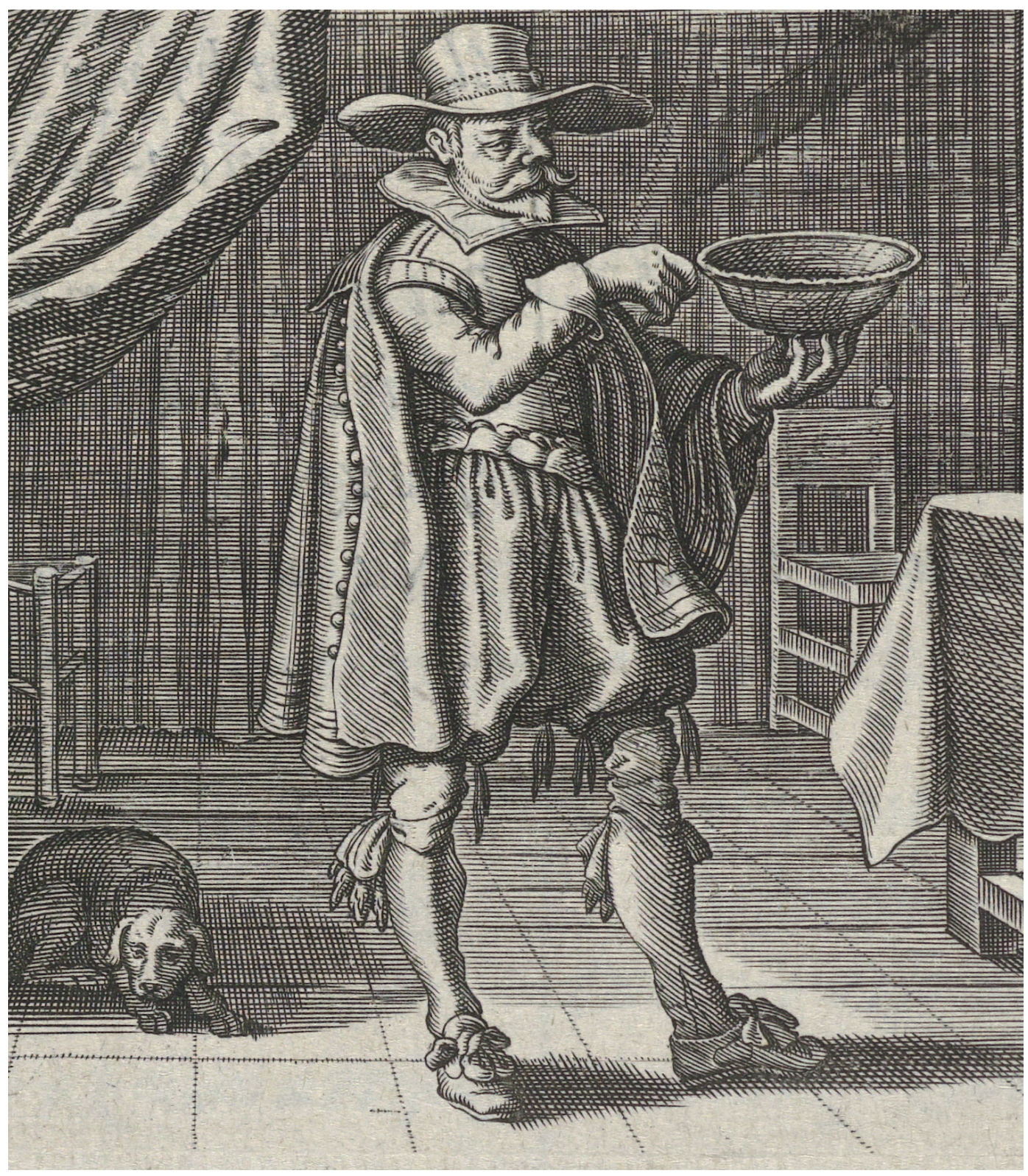

Detail uit Jan de Brune,

Emblemata of Zinnewerck,

Amsterdam, 1636, tweede,

vermeerderde druk 
East Asia, ceased control of sea due to its dynastic transition in the early 17th century. As Sakuraba's chapter denotes, Japanese Imari porcelain decorated with colorful over-glazed enamel replaced Chinese blue-and-white porcelain and became the most popular product in the European market, Christiaan Jörg's 'A change in taste: the introduction of enameled export porcelain in the 17th century' serves as the immediate response to the reader's curiosity. Antonia Malan and Jane Klose's chapter, 'Porcelain at the Cape of Hope in the 17th century', then, not only brings our attention back to the western hemisphere but also offers a glimpse to the daily life at the locale with archaeological finds.

Chapters Ten to Twelve examine the European perception of Chinese porcelain and how Chinese porcelain was addressed local political and gendered significance. Cordula Bischoff's 'Women collectors and the rise of the porcelain cabinet' articulates the collecting activities of female members in the marital genealogy of Houses of Orange, Brandenburg and Kassel; Jan van Campen's 'Chinese and Japanese porcelain in the interior' looks at how the Asian commodities were displayed and used by Dutch merchants when these objects became obtainable in the 17th century. In comparison, Thijs Weststeijn's 'Cultural reflections on porcelain in the 17th-century Netherlands' examines 'Chinese porcelain' as a concept rather than object. The anthology is concluded by 'Imitation and inspiration: the artistic rivalry between Dutch delftware and Chinese porcelain' written by Suzanne Lambooy. As its title suggests, the article contextualizes the path of Dutch delftware from copying the Chinese original in the 17th century to developing its identity as an outstanding craft a century after.

While Eurasian cultural interaction of the 17th century is hardly a new realm of research, Chinese and Japanese Porcelain for the Dutch Golden Age sheds new lights on the field for its balance among visual, textual and archaeological evidence. In particular, the excavated shards from the Netherlands and the Cape of Hope analyzed by Ostkampt and Malan/Klose enrich our understanding of the kinds of ceramic utensils used in people's daily life. With the definite dates of the excavation sites in the Netherlands, Ostkampt confirms the juxtaposition of Chinese and Japanese porcelain pieces in local households. More interestingly, he points out the phenomenon that many of the 17th-century Kraak and Transitional wares were found from much later sites, signifying the degree to which these porcelains were cherished, something that rarely happened to other types of ceramic wares (pp. 76, 79). It then enriches the study of the 'afterlife' of the trade ware, that is, trade ware as antique collectables, from the archaeological perspective. On the other hand, Malan and Klose's chapter on the excavation at the Cape of Hope provides invaluable material evidencing the diversity of porcelain on the VOC ships by the time it returned from the eastern hemisphere. The discovery of Persian frit-ware dishes and bowls from the shipwrecks off the cape, such as the Oosterland of 1697, and on Cape land sites are the physical evidence that the trade of Islamic pottery continued into the early 18th century (p. 154).

Another noteworthy type of scholarship included in this anthology is the connection between trade ceramics and the latest trends in material culture

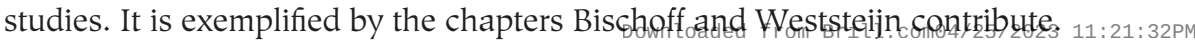


The former investigate the significance of porcelain cabinet to early modern female descendants of the house of Orange. Through contextualizing the entangled genealogy of these women and their possession of Chinese and Japanese porcelain, their channels of collecting, and the ways how porcelain wares were displayed in their interior space, Bischoff articulates these women's choice of Asian porcelain, along with other Asian objects, as a symbol of their Dutch and female identity. On the one hand, since cabinets were commonly installed in women's interior space, it also underlined the owner's female identity. On the other hand, blue-and-white porcelain from China and Japan were almost exclusively imported by the VOC and thus would easily remind the viewer of a lush porcelain cabinet of its owner's wealth, high social standing and Dutch association. In comparison, Weststeijn's chapter considers Chinese porcelain from a semiotic point of view. The author analyzed the developing definition of this term in 17thcentury Dutch epistemology, demonstrating its interesting transition from mythical exotica to the signifier of a remote utopia, and how its materiality triggered Western intellectual interest in understanding Chinese civilization in a systematic manner in the 18th century. 'Chinese porcelain' as a concept, according to the author, was connected with medicine and magic. For Dutch still-life painters, it was understood both as a creation of nature and as a creation of artifice (p. 217). As a symbol of global trade in Dutch pictures, 'Chinese porcelain' was often associated with Africa due to the Dutch public's interest on the thriving VOC represented by the abundance of porcelain rather than the rational understanding of the civilization that created porcelain (p. 227), which only interested intellectual souls such as Isaac Vossius (1618-1689), who stated that China was a superior civilization whose excellence in art and music, literature and science embodied in its porcelain production (p. 229). The author therefore articulates different layers of imagining China in 17th to 18th-century Dutch society.

If I should wish for any addition to this marvelous anthology, it would be more discussion on the end of production, that is, how Kraak porcelain was made and possibly used in China. Although only sporadic archaeological reports of kilns that used to produce Kraak porcelain are published, ${ }^{4}$ it is confirmed that both Jingdezhen in Jiangxi Province and Pinghe in Fujian Province used to be the production centers of Kraak porcelain, although the quality of the latter was lower. In addition to the excavation from the kiln sites, Kraak porcelains also appeared in 17 th-century tombs near Jingdezhen. They were no longer utensils for the funerary rituals but epitaphs as short bibliographies of the tomb occupants were written on the unglazed porcelain bottoms. ${ }^{5}$ It implies that the Kraak porcelain was indeed not for Chinese domestic market, and it was possibly even regarded an interesting rarity for special purposes as there might have been a streamline of brokering, production and shipping separate from kilns making wares for the domestic market. Chinese and Japanese porcelain for the Dutch Golden Age is thus a great reading for both exports of the field and anyone interested in 17thcentury Eurasian cultural exchange.

- Ying-chen Peng is Assistant Professor at the Department of Art, American University, Washington D.C. She specializes in late imperial and modern Chinese art history with a focus on gender issues and globalization of material culture. She is also conducting research on the Chinese porcelain industry in the 19th and early 20th centuries. 
- Chinese and Japanese Porcelain for the Dutch Golden Age

Titus Eliëns en Jan van Campen (eds), 2014. Published by Waanders Uitgevers. ISBN 978949119680

\section{Notes}

1. T. Volker, Porcelain and the Dutch East Indian Company, Brill, Leiden, 1971; Porcelain and the Dutch East Indian Company, Brill, Leiden, 1959.

2. Christiaan Jörg and Oliver Impey, Fine and Curious: Japanese Export Porcelain in Dutch Collection, Hotei Publishing, Leiden, 2003; Christiaan Jörg, Chinese Porcelain in the Rijksmuseum, Rijksmuseum Amsterdam, 1997.

3. Robert Finlay, The Pilgrim Art: Cultures of Porcelain in World History, University of California Press, Berkeley, 2010.

4. Cao Jianwen, 'Xunmi yijiu de Jingdezhen Kelakeci yaozhi bei faxian (Kilns of Kraak porcelain in Jingdezhen long been searched are discovered),' Zhongguo wenwubao April 17, 2002; Fu Songliang, 'Fujian Pinghe faxian de Kelakeci dapan (Large plates of Kraak porcelain are found in Pinghe, Fujian Province),' Wenwu (2001) 11: 85-92.

5. Yao Chengqing, Yao Lianhong, 'Jiangxi yanjiu Kelakeci de xinjinzhan - san tan Jiangxi jinianmu chutu de "furongshou" (New development of the research of Jingdezhen Kraak porcelain: the third discussion on the 'peony-type or fuyode' excavated from dated tombs in Jiangxi province),' Jingdezhen taoci vol. 9/2-3 (1999): $62-7$. 


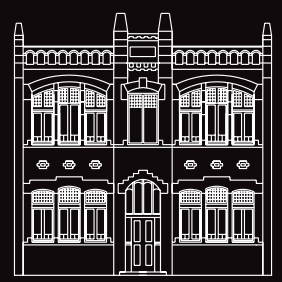

\section{ZeEuWs Veilinghuis}

Z E E L N D A U C T I O N E R S

\section{4}

\section{MAART}

\section{5}

\section{AzIATICA VEILING}

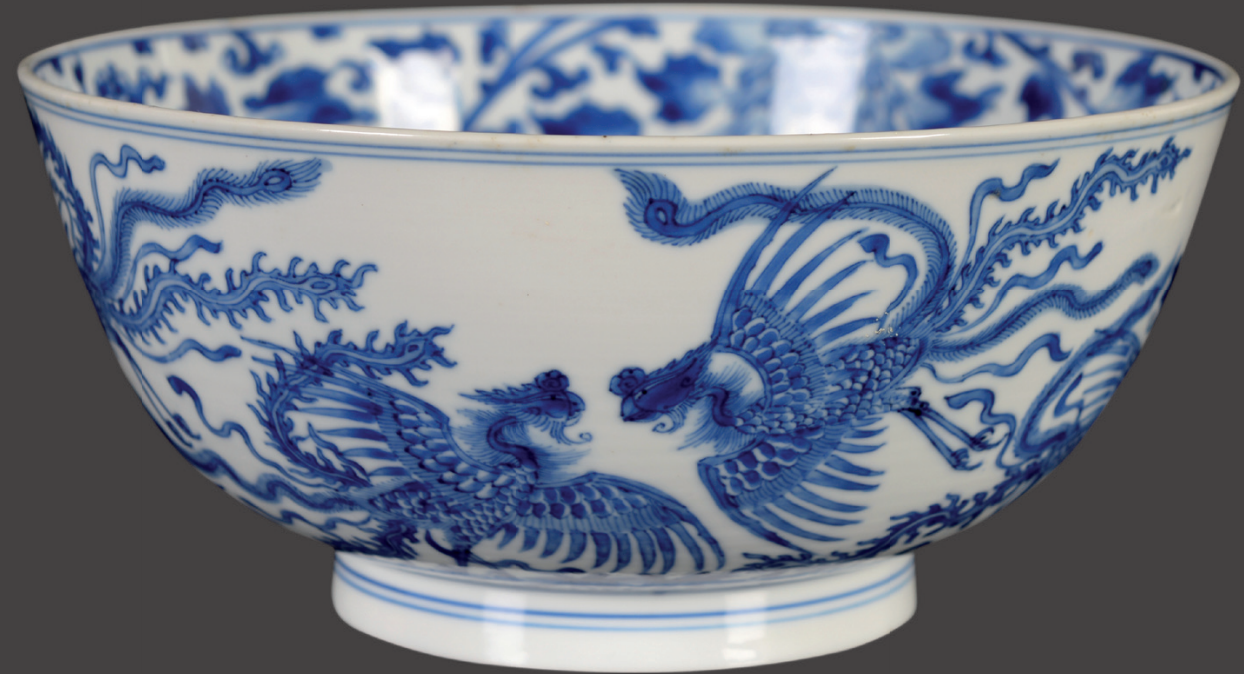

\section{KiJKDAGEN:}

VRIJDAG 2O MAART: I 3 - I7 UUR ZATERDAG 2I MAART: IO - I 6 UUR
MAANDAG 23 MAART: I 3 - I 7 UUR DINSDAG 24 MAART: IO - I 2 UUR

Herengracht 744331 PX Middelburg WWW.ZEEUWSVEILINGHUIS.NL | INFO@ZEEUWSVEILINGHUIS.NL 

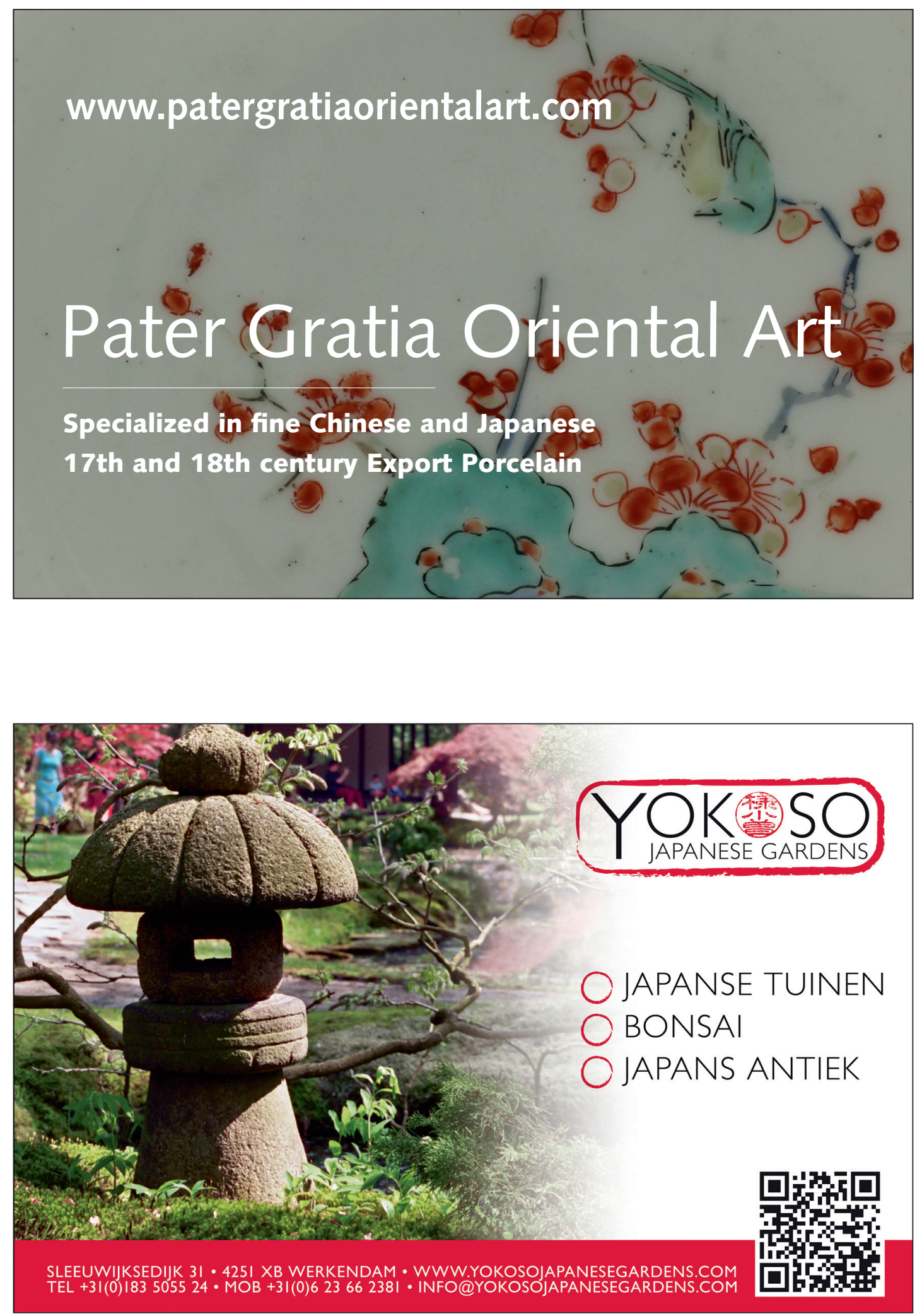


\section{Littleton \& Hennessy ASIAN ART}

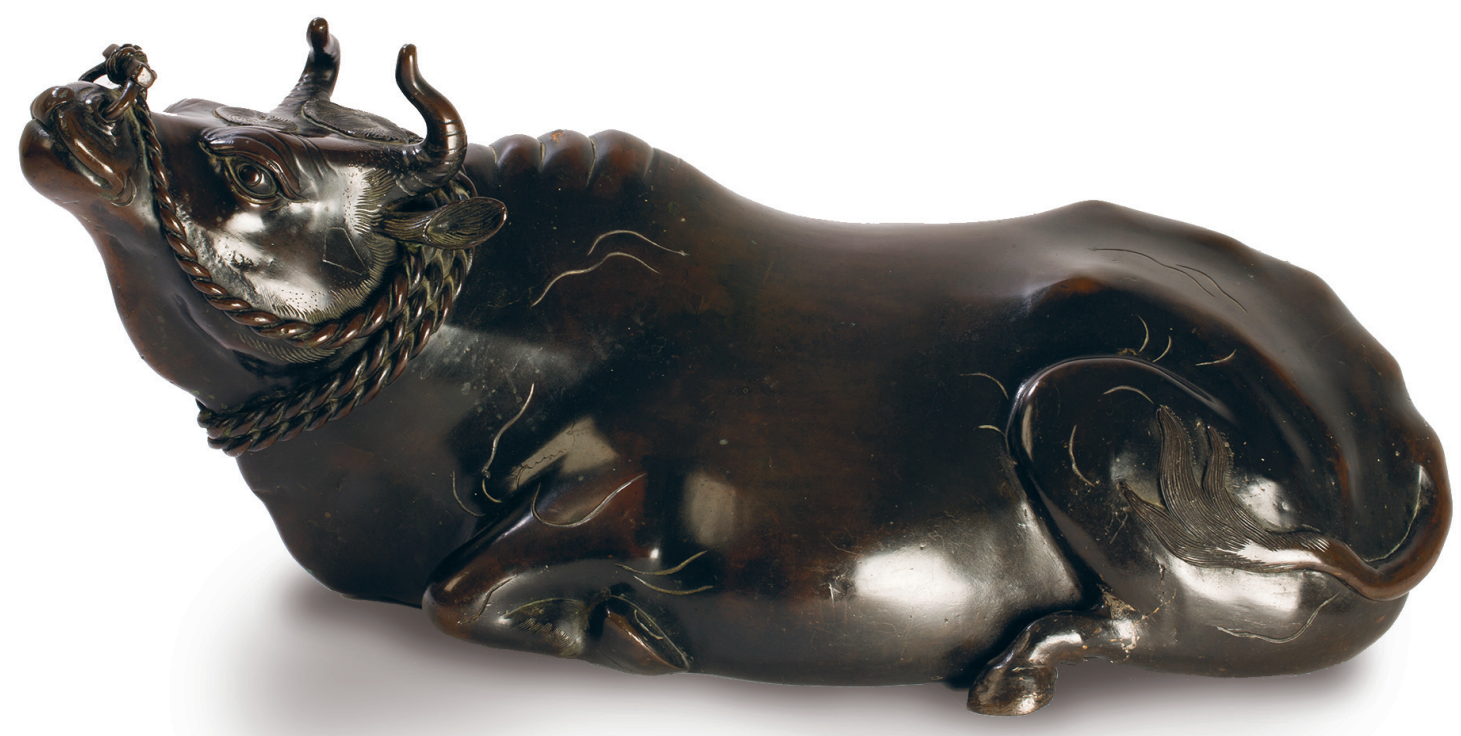

A LARGE BRONZE FIGURE OF A WATER BUFFALO

17 th/18th century

Dimensions: 27.5 x $64 \mathrm{~cm}$

Voor verdere inlichtingen, taxaties en consignaties (Nederlands): Dhr. Mark Slaats mark@littletonandhennessy.com

Tel.: +447717 825828

Bezoek ons tijdens TEFAF Maastricht (stand 269)

1 Princes Place, Duke Street

St. James's, London SW1Y 6DE

$\mathrm{T}:+44(0) 2079300888$

F: $+44(0) 2079304988$

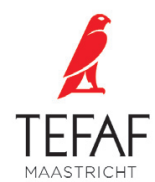

Suite B, 13/F, Shun Ho Tower 24-30 Ice House Street Central, Hong Kong T: 85225415779 


\section{GUUS RÖELL FINE ART}

Tel.: 0653211649 | e-mail: g.roell@planet.nl | website: www.guusroell.com Tongersestraat 2, $6211 \mathrm{LN}$ Maastricht

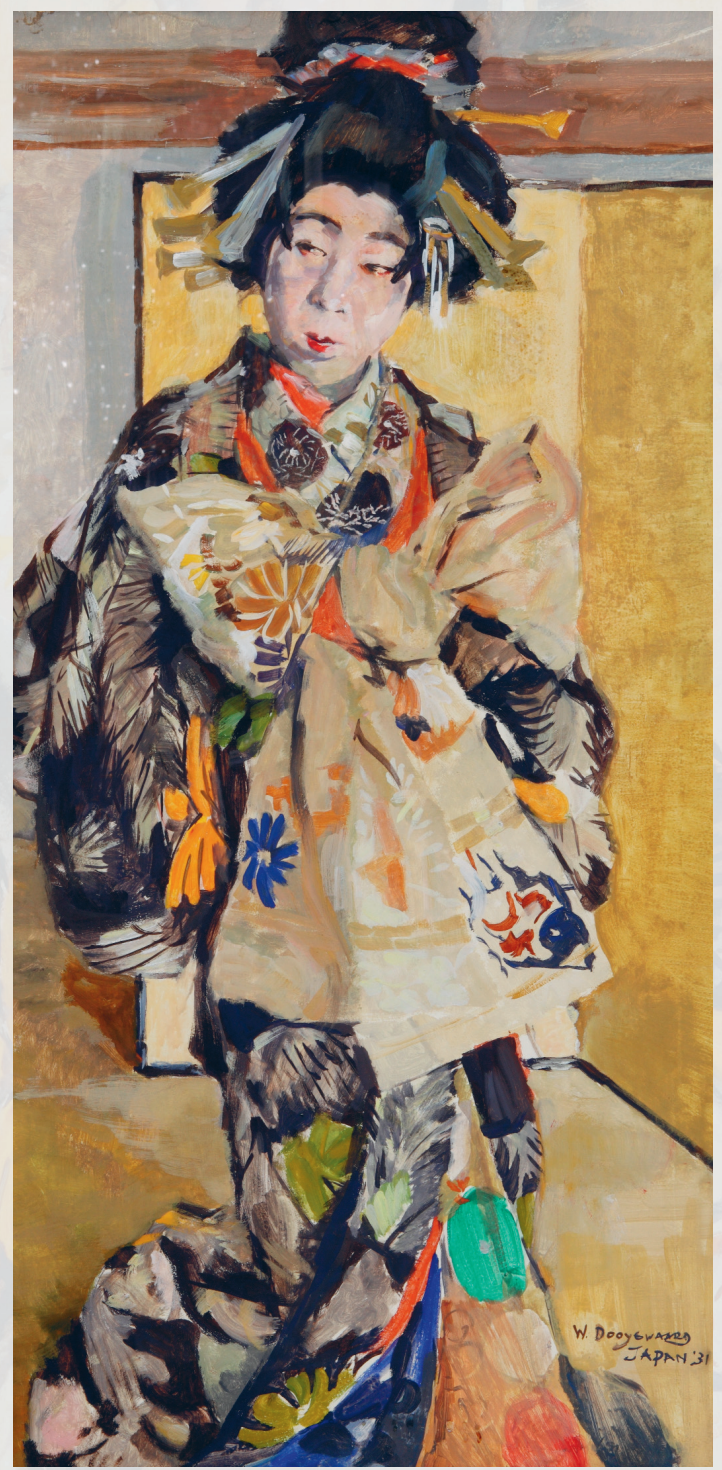

Willem Dooyewaard (1892-1980), "Tayu figuur" (geisha van de hoogste rang), Pastel op papier, gesigneerd "W Dooyewaard, Japan '31". 88 x $43 \mathrm{~cm}$. 


\section{Astamangala}

OUDE KUNST UIT TIBET, NEPAL EN INDIA

KEIZERSGRACHT 574 • 1017 EM AMSTERDAM (SPIEGELKWARTIER)

TEL: 020-6234402・E-MAIL: ASTA@XS4ALL.NL・WWW.ASTAMANGALA.COM

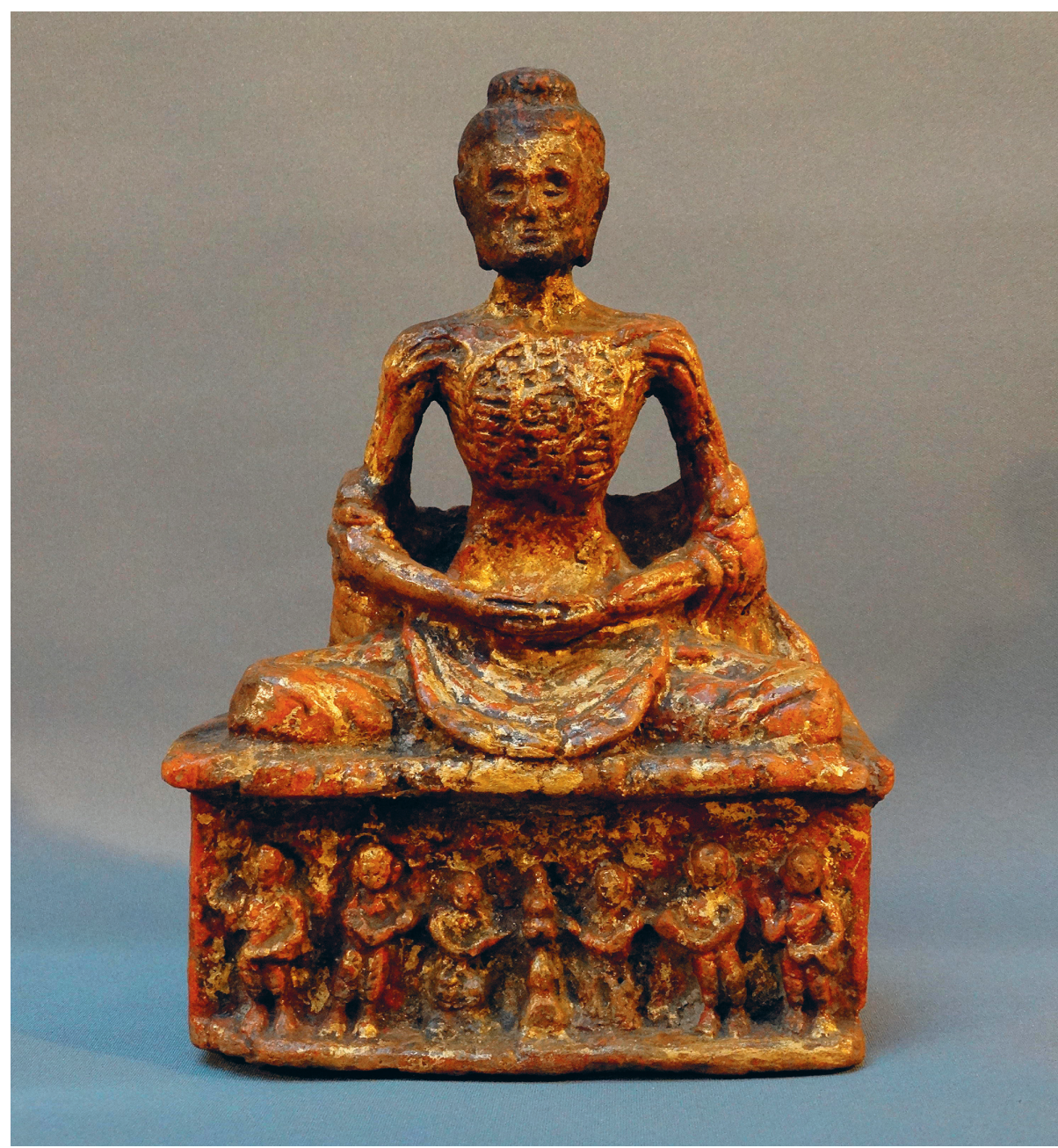

Siddhartha Gautama als uitgemergelde asceet, Thailand, $15^{\mathrm{de}}-17^{\mathrm{de}}$ eeuw (Thermoluminescence test Oxford N20of54) beschilderd en verguld terracotta, hoog: $17 \mathrm{~cm}$.

Zeer zeldzame voorstelling, die bijna letterlijk 'overgenomen' is van voorbeelden uit de Gandhara-periode $\left(1^{\text {ste }}-3^{\text {de eeuw }}\right.$. Enige voorbeelden uit Thailand uit de $19^{\text {de }}$-begin $20^{\text {ste }}$ eeuw zijn bekend in brons, maar dit is, voor zover ik weet, het enige bekende vroegere voorbeeld in terracotta. 


\section{Frides Laméris}

\section{KUNST- EN ANTIEKHANDEL VOF}

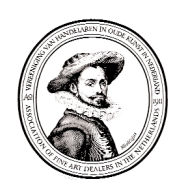

Nieuwe Spiegelstraat 55 IOI7 DD Amsterdam Telefoon 020-6264066 info@frideslameris.nl www.frideslameris.nl glas - ceramiek objets de collection

Kop en schotel beide met een beschildering van een schip, een eilandje, een vioolspelende meermin en rotsen in zee. Langs de rand op een banderol de inscriptie 'GARDES vous DE la SyRene'. Kangxi, eind zeventiende eeuw.

H. kop 4,9 cm, Ø 8,9 cm, Ø schotel I3,4 cm.

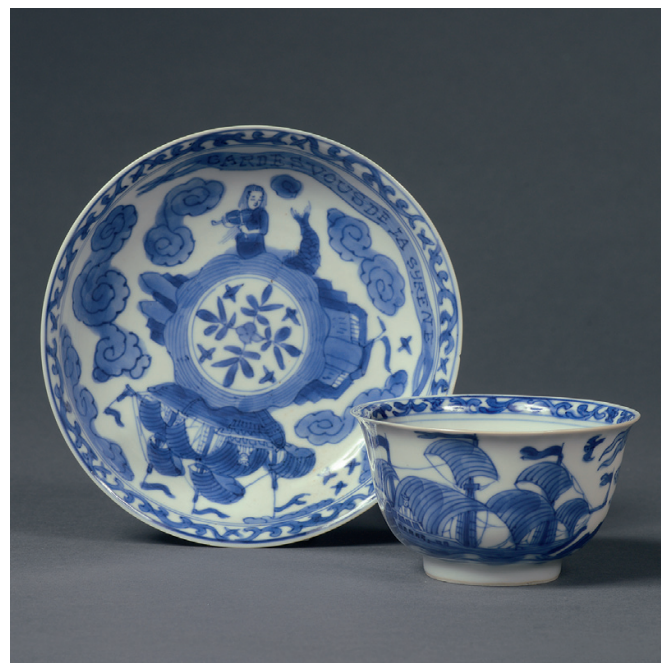

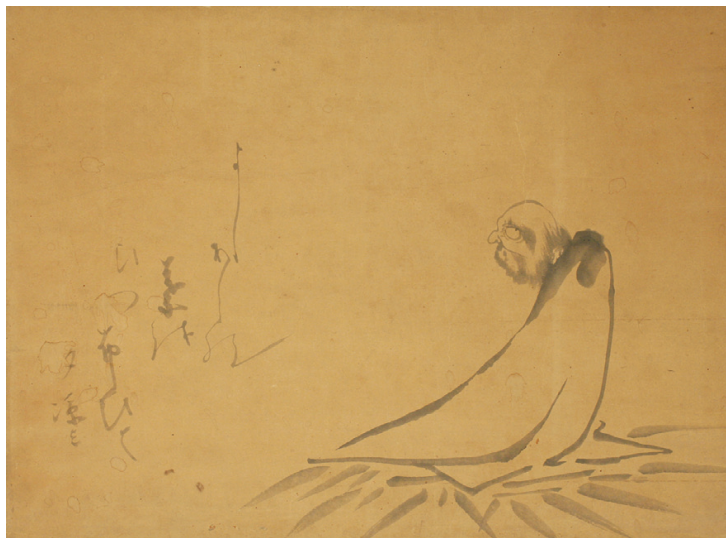

Hakuin (I685-1768) - Daruma yûsuzu

"Zittend op bies en riet (goed en slecht) genietend van de avondkoelte."

\section{$M B$ ASIAN ART AB IN BRUSSELS Sablon, June $10^{\text {th }}$ to $14^{\text {th }}$}

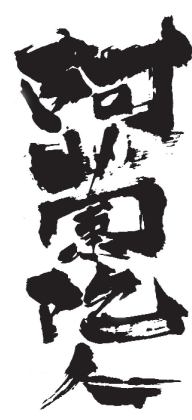

\section{ORANDA JIN}

Japanese paintings \& painters' pottery

Jon de Jong

Kalverstraat 28, $5223 \mathrm{AD}$ 's-Hertogenbosch

tel: +31 (0)73-621 8951

e-mail: orandajin@home.nl

www.orandajin.com

(nieuwe update eerste week van de maand) 


\section{Wij gaan met muziek naar onze vrienden}

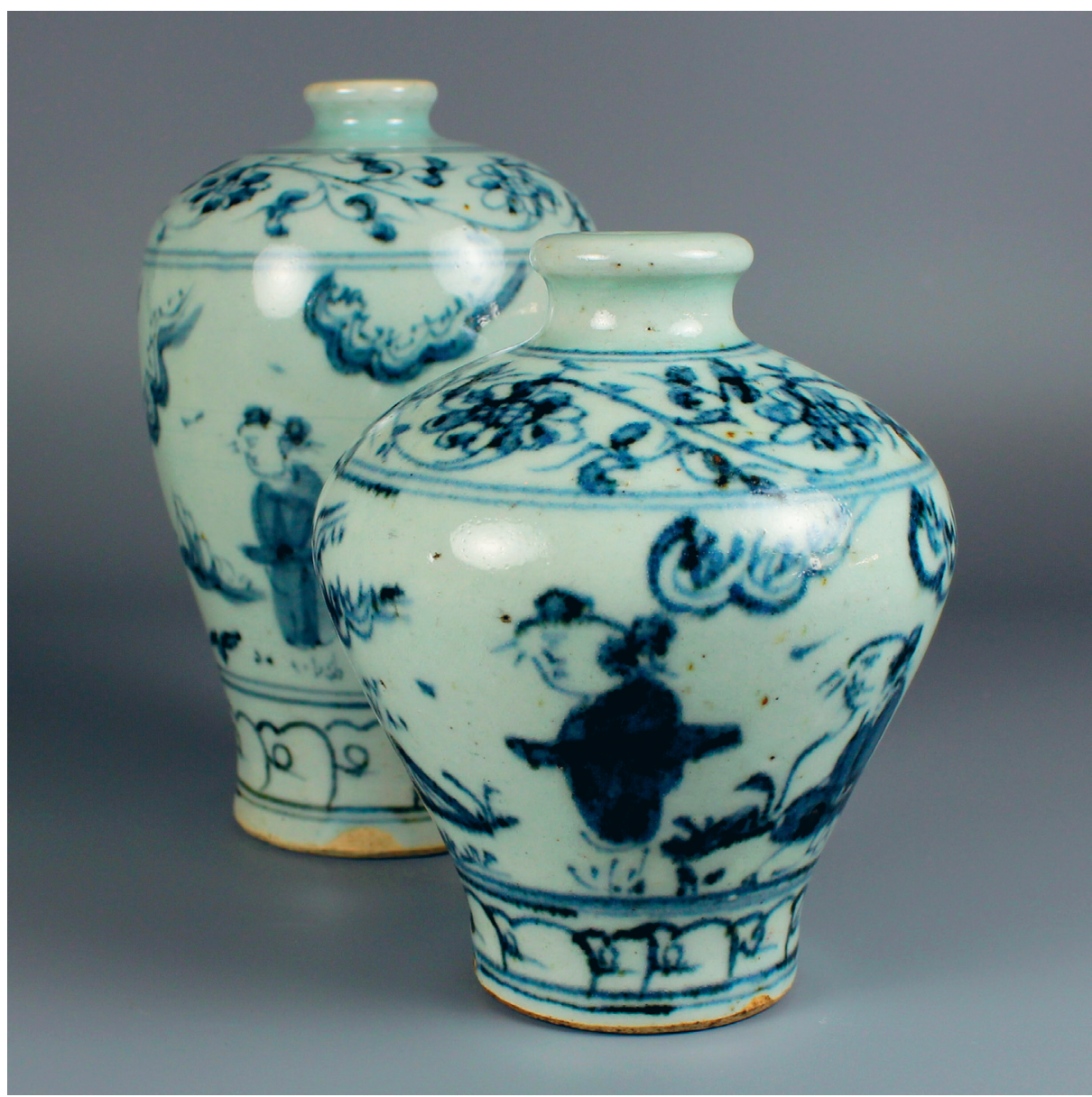

Stel zeldzame blauw en wit porseleinen meiping vazen met een thema: "Wij gaan met muziek naar onze vrienden" MING DYNASTY XUAN DE PERIODE（I425-I435）

Openingstijden: din. t/m zat. van II:OO-I7:00 u en zondag van I3:00-I7:00 u Email: chinaartgallery@hotmail.com

\section{www.gallery-china-art.nl}

Mariniersweg $24 \cdot 3$ OII NN Rotterdam • Tel: oIO-229 3583 


\section{GEVRAAGD}

Chinees porselein en Aziatische kunstvoorwerpen voor de komende kunst- en antiekveiling van 2-5 juni 2015

Reeds ingebracht voor veiling juni 2015:
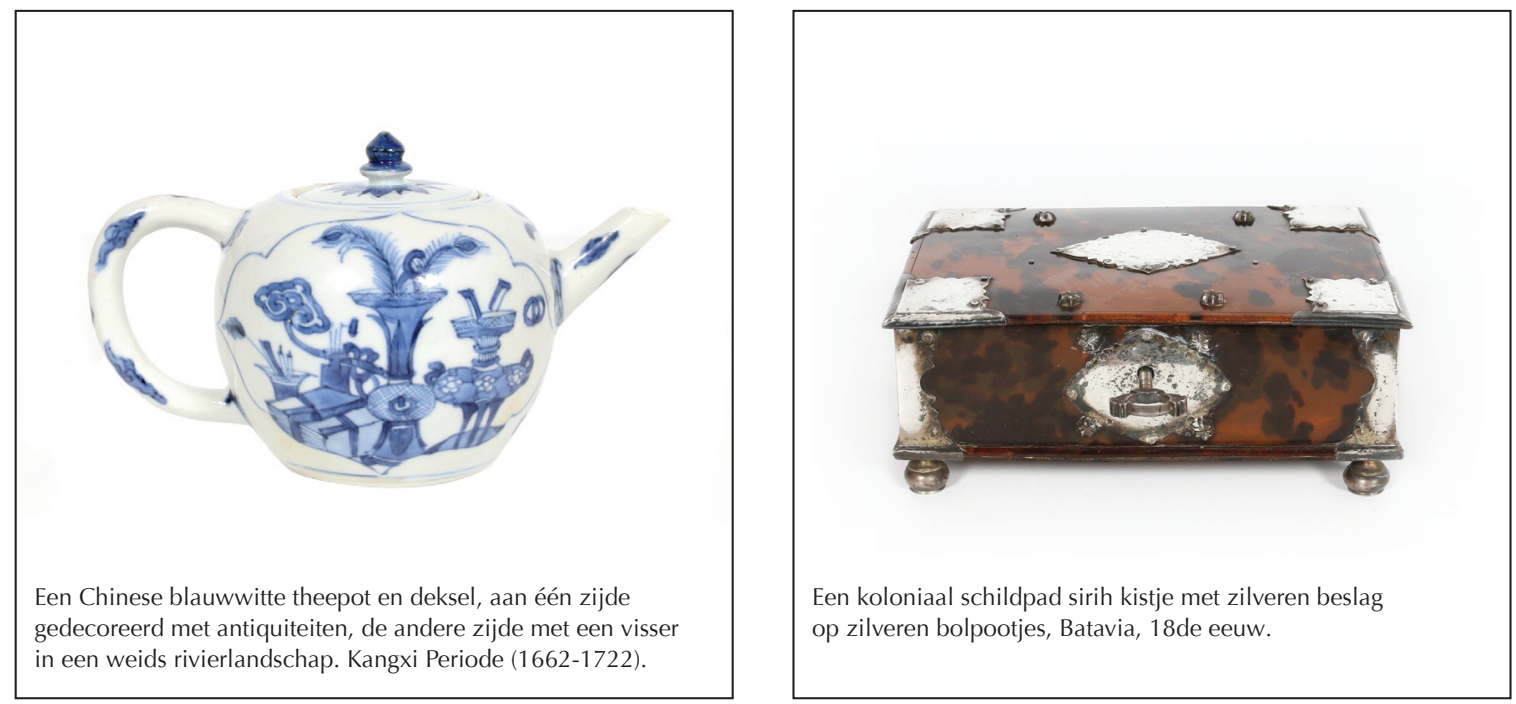

Resultaten:

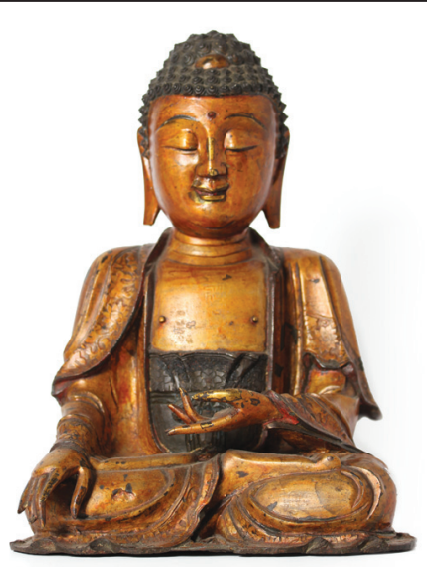

Een Chinees verguld bronzen Boeddha gezeten in vajrasana, 17e eeuw, veiling 13 november 2012, hamerprijs EUR 38.000

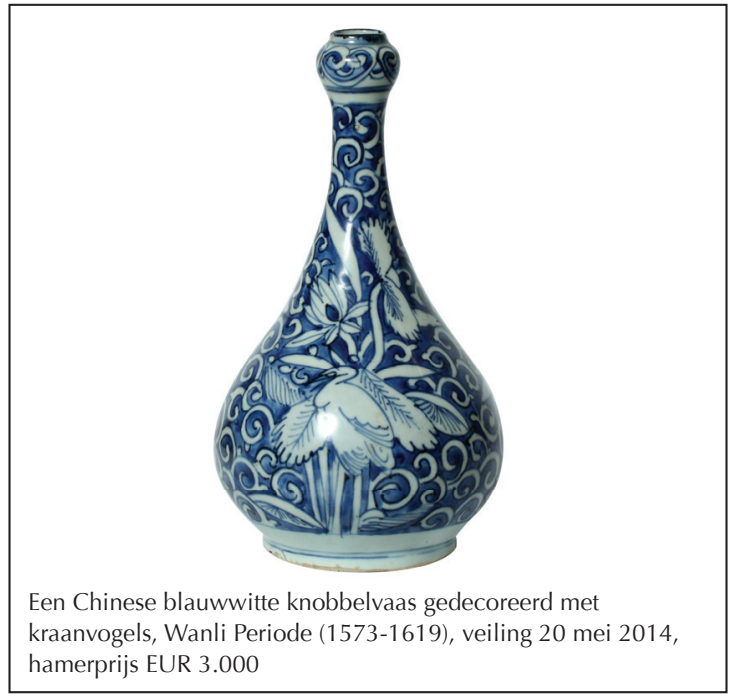

Inbreng mogelijk tot 7 april

Kipstraat 54, 3011 RT Rotterdam

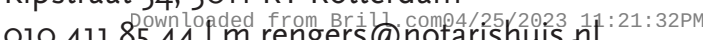




\section{SYMPOSIUIM GRONINGER MUSEUM}

\section{BREEKBAAR GOED EEN EERBETOON AAN MINKE A. DE VISSER}

25 MAART $2015 \diamond$ 14.00-17.00 UUR $\diamond$ GRATIS

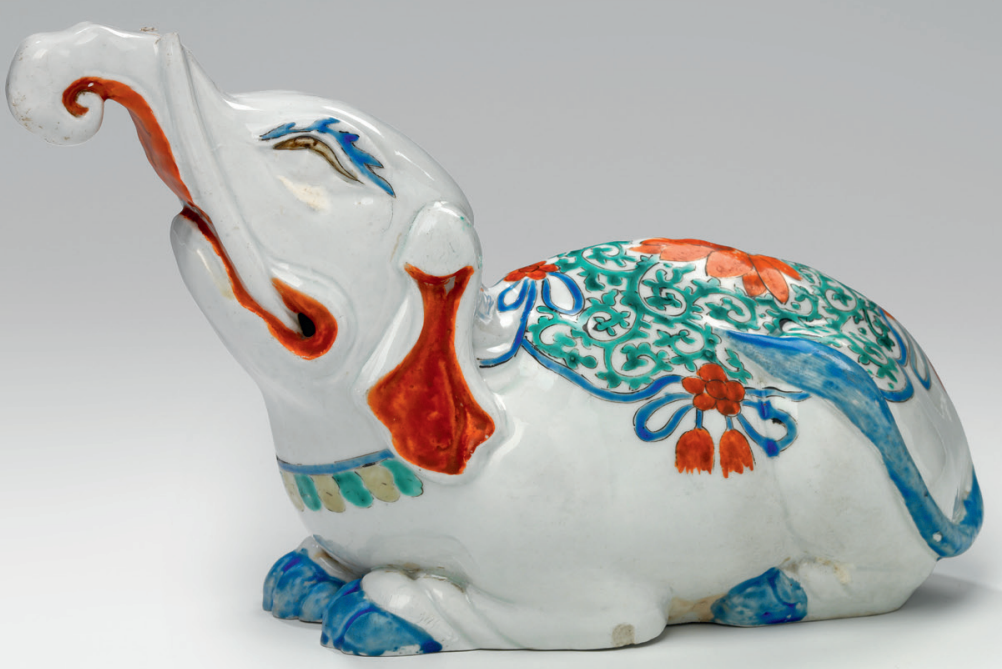

14:00 Ontvangst met koffie en thee

\section{4:30 Lezingen}

Ontstaansgeschiedenis collectie Aziatische Keramiek in het Groninger Museum

Caspar Martens over het verzamelbeleid van Minke de Visser

Christiaan Jörg over zijn verzamelbeleid

15:30 Bezichtiging tentoonstelling: Breekbaar Goed.

Een eerbetoon aan Minke de Visser.

16:00 tot 17:00 Receptie in de Job Lounge.

U kunt zich inschrijven via:

symposium@groningermuseum.nl

Na uw inschrijving ontvangt u digitaal een bevestiging. Die bevestiging is tevens uw bewijs van toegang.
Minke A. de Visser was van 1921 tot 1966 verantwoordelijk voor de collectie keramiek in het Groninger Museum. Als autodidact wist zij zichzelf te ontwikkelen tot een, in zowel binnen- als buitenland, gerespecteerde expert op het gebied van porselein en aardewerk.

Door haar inspanningen werd de verzameling aanzienlijk uitgebreid met diverse schenkingen, legaten en aankopen. Zij wist hiermee de basis te leggen voor een van de belangrijkste verzamelingen op dit gebied in Nederland.

Haar opvolger Prof. dr. Christiaan Jörg bouwde de verzameling verder uit en publiceerde talloze boeken over Chinees en Japans export porselein.

De tentoonstelling Breekbaar Goed. Een eerbetoon aan Minke de Visser is van 20 maart 2015 t/m 15 maart 2016 te zien in het Groninger Museum.

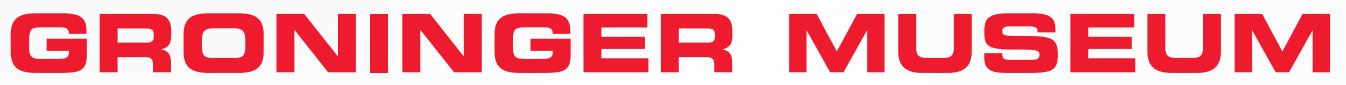




\section{MARCEL NIES ORIENTAL ART}

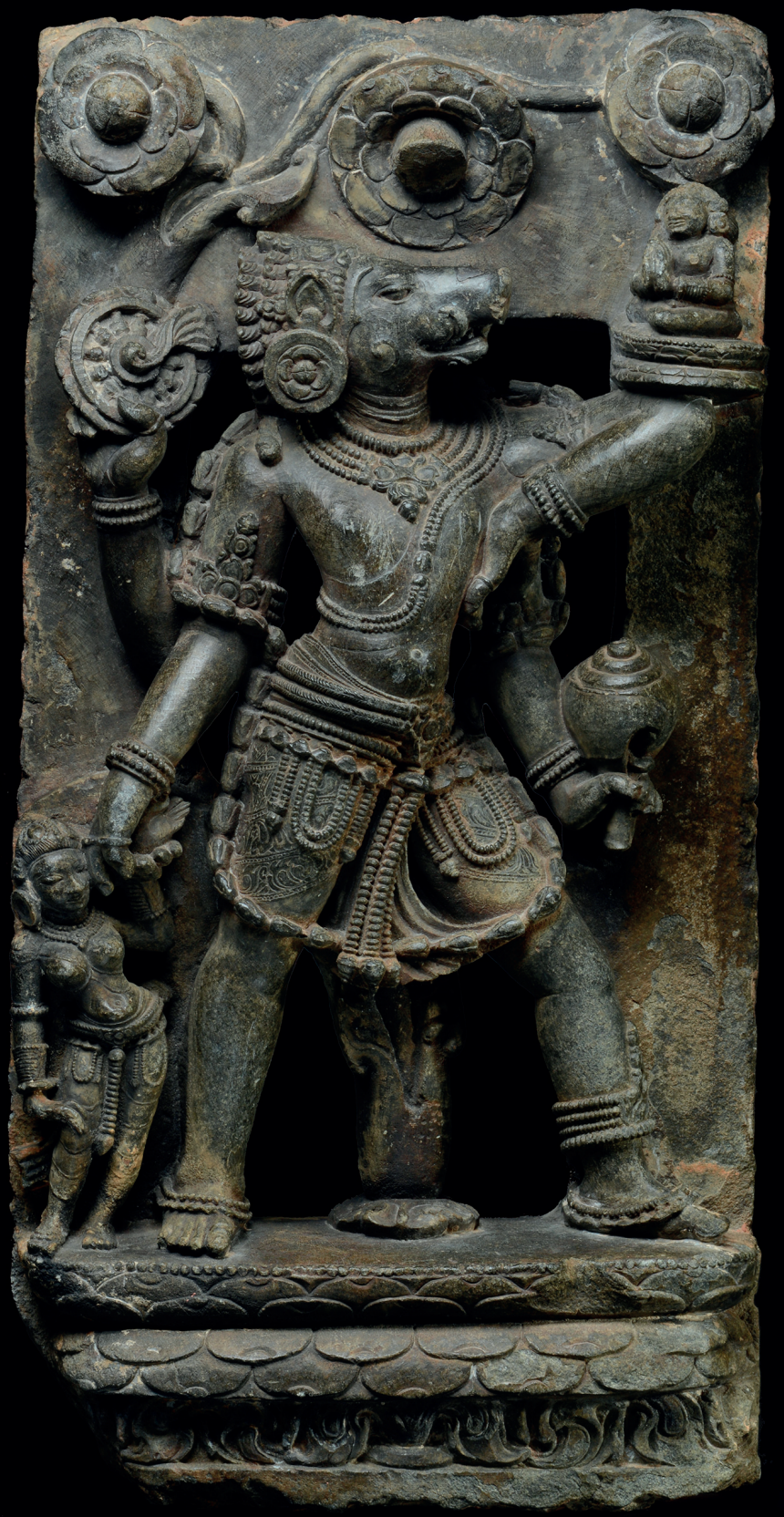




\section{BASTINGS ANTIQUAIRS}

Al meer dan 50 jaar specialisatie van o.a. Chinees en Japans porselein uit de $16^{\mathrm{e}} \mathrm{t} / \mathrm{m}$ de $18^{\mathrm{e}}$ eeuw

Voorjaar expositie met gastdeelnemers $13 \mathrm{t} / \mathrm{m} 15$ \& $20 \mathrm{t} / \mathrm{m} 21$ maart

Deelnemer Artfair Den Bosch (Autotron) $18 \mathrm{t} / \mathrm{m} 27$ april

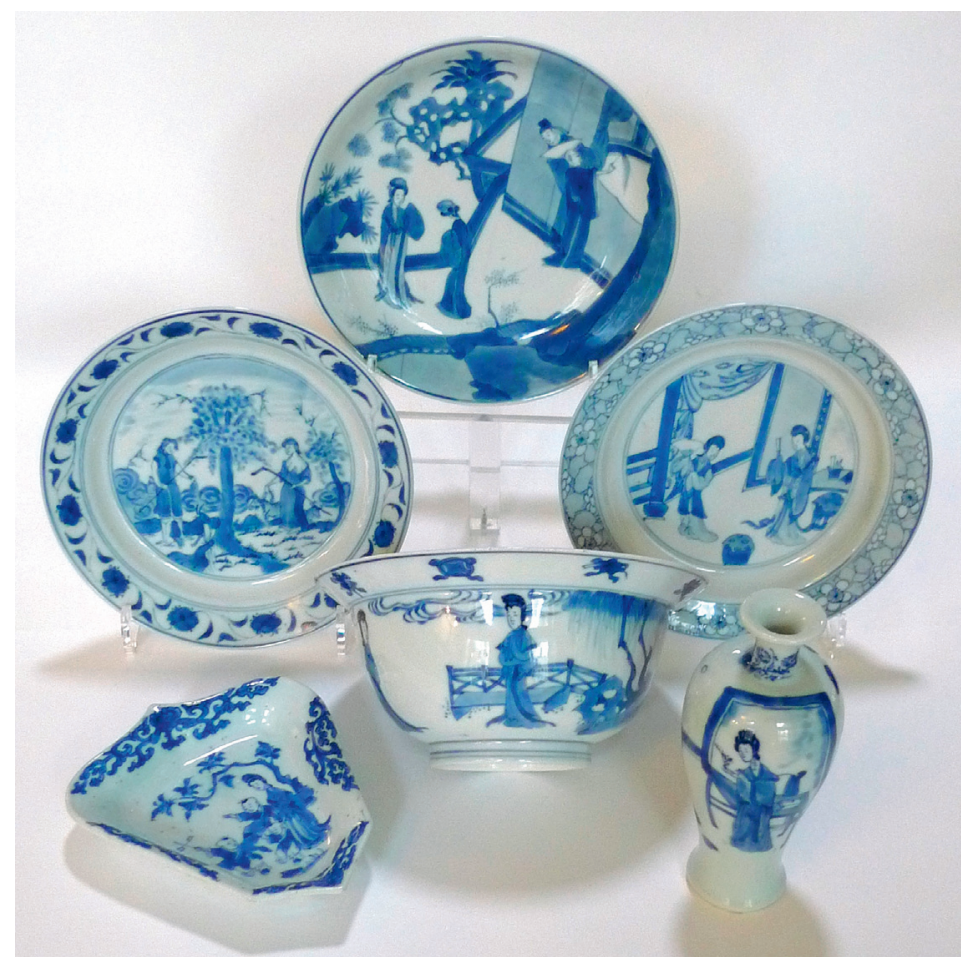

Collectie aanwinsten Chinees porselein met decoratie van 'long Elisa' en 'Adam \& Eva' (een greep uit de collectie Kangxi porselein 1662-1722)

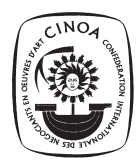

Adres:

Molenstraat 58/60

5341 GE Oss

(ruime eigen parkeer-

gelegenheid aanwezig)
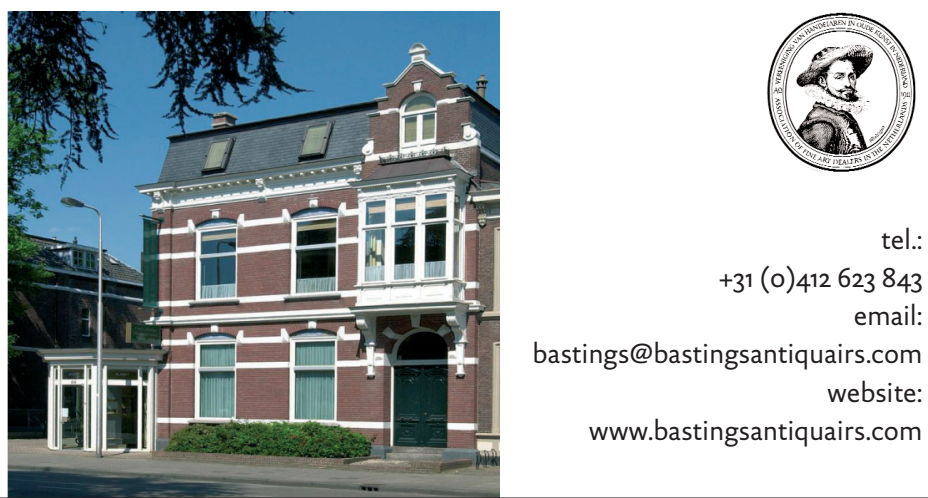

tel.:

$+31(0) 412623843$

email:

bastings@bastingsantiquairs.com

website:

www.bastingsantiquairs.com 